\title{
Physiological and Biochemical Changes Induced by UV-B Radiation in Rosemary Plants Grown Under Salinity Stress
}

\author{
Abolghasem Hamidi Moghaddam' ${ }^{1}$, Hossein Arouiee ${ }^{1 *}$, \\ Nasrin Moshtaghi'2, Majid Azizi', Mahmoud Shoor', Fatemeh Sefidkon ${ }^{3}$ \\ 1 Department of Horticulture and Landscape Engineering, Faculty of Agriculture, Ferdowsi University of \\ Mashhad, Mashhad, Iran \\ 2 Department of Crop Biotechnology and Breeding, Faculty of Agriculture, Ferdowsi University of Mashhad, \\ Mashhad, Iran \\ ${ }^{3}$ Research institute of Forests and Rangelands, Tehran, Iran \\ * Corresponding author's e-mail: aroiee@um.ac.ir
}

\begin{abstract}
Plants are exposed to solar ultraviolet radiation due to use of sunlight for photosynthesis. Additionally, salinity in soil or water influences the plant productivity and quality considerably. Moreover, when plants are simultaneously exposed to multiple stresses, one form of stress can affect the response to other stress. Particularly, it has been shown that they can benefit from dual tolerance as salinity and UV-B radiation are applied together. In order to understand the effects of UV-B radiation and salinity stress on some physiological and biochemical parameters, one-year-old cuttings of rosemary plants were grown under different levels of ultraviolet $B$ radiation $\left(0,4.32\right.$ and $\left.6.05 \mathrm{~kJ} \mathrm{~m}^{-2} \mathrm{~d}^{-1}\right)$ and salinity stress (control, 50,100 and $150 \mathrm{mM} \mathrm{NaCl}$ ). The results showed that $4.32 \mathrm{~kJ} \mathrm{~m}^{-2} \mathrm{~d}^{-1} \mathrm{UV}-\mathrm{B}$ treatment significantly increased plant biomass up to $17.9 \%$ as compared to control. However, by increasing salinity to $150 \mathrm{mM}$, plant biomass significantly decreased up to $18.1 \%$, as compared to control. Regardless of UV-B treatments, plants, grown under $100 \mathrm{mM}$ salinity stress, had produced 2.8 times higher total phenolic compounds (TPC) and also have greater antioxidant activity (33.1\%) in comparison to control. Both treatments, enhanced UV-B radiation and salinity stress, significantly increased the concentration of proline, hydrogen peroxide $\left(\mathrm{H}_{2} \mathrm{O}_{2}\right)$ and malondealdehyde (MDA). In relation of total soluble sugar (TSS) and ion content, both treatments acted in an opposing manner. In turn, the enhanced UV-B radiation decreased concentration of TSS and the $\mathrm{Na}^{+}$content in leaves, salinity stress increased the concentration of TSS, as well as the $\mathrm{Na}^{+}$content in leaves and root. The plants grown under $150 \mathrm{mM}$ salinity level accumulated 5.32 and 2.83 times higher $\mathrm{Na}^{+}$ions in leaves and roots, respectively, than control. In addition, salinity significantly decreased the relative water content (RWC), photosynthetic pigments and $\mathrm{K}^{+}$content in leaves and roots. The interaction between UV-B irradiation and salinity showed that the UV-B radiation improved the $\mathrm{K}^{+}$content in leaves, RWC and membrane stability and consequently resulted in a better tolerance of rosemary to salinity.
\end{abstract}

Keywords: antioxidant activity, cross-tolerance, hydrogen peroxide, ion contents, total phenolic compounds

\section{INTRODUCTION}

Plants often undergo a wide range of environmental stresses such as unfavorable temperatures, nutrient stress, water shortage, salinity, high ultraviolet radiation, etc., in their life cycle, which reduce the plant production (Hasanuzzaman et al., 2013). They are exposed to different levels of solar UV-B irradiation due to use of sunlight for photosynthesis, it's the level of which increased during the last decades due to ozone depletion, reduction of cloudiness and other factors (McKenzie et al., 2011). Compared to the high levels of ultraviolet $\mathrm{B}$ radiation which are exclusively stressor factor, recently clarified that its low levels acted as an important regulator of plant secondary metabolites (Schreiner et al., 2012). In particular, it is well-known that biosynthesis and accumulation of phenolic compounds, which are mainly found in leaf epidermal cells, constitute a general 
mechanism of increasing the UV-B radiation (Reboredo and Lidon, 2012; Bernal et al., 2013).

Salinity in growth medium is one of the most important limitation factors for the plant growth. At high concentrations, it leads to water deficit, toxicity of salt ions, nutrient imbalances, membrane damage, change in enzyme activation, etc., and ultimately to death (Mahajan and Tuteja, 2005; pessarakli, 2010).

The previous studies reported that high level of UV-B radiation (Rai et al., 2011; Takshak and Agrawal, 2014; Shen et al., 2015;) and salinity (Tanou et al., 2009; Wang et al., 2016; El-Esawi et al., 2017) caused a disturbance in plant normal metabolism by accelerating the generation of reactive oxygen species (ROS). Accumulation of $\mathrm{H}_{2} \mathrm{O}_{2}, \mathrm{O}_{2}^{-}$and $\mathrm{OH}^{-}$in plant cells lead to peroxidation of unsaturated fatty acids of membranes (Karima and Salama, 2009 and Shen et al., 2015).

It has been argued that $\mathrm{H}_{2} \mathrm{O}_{2}$ at low concentration is one of the main and the most stable reactive oxygen species that regulates basic acclimatization, defense and developmental processes in plants as a messenger molecule in several processes. Pre-exposure of plants to UV-B radiation, which induces the generation of $\mathrm{H}_{2} \mathrm{O}_{2}$, can have a protective function and "immunize" them to other stresses (Kovtun et al., 2000). The expression of some genes such as the antioxidant genes, defense proteins and proteins involved in signaling like calmodulin, protein kinases, phosphatases, and transcription factors is dependent on $\mathrm{H}_{2} \mathrm{O}_{2}$ (Neill et al., 2002; Tanou et al., 2009). Nevertheless, at high concentrations, hydrogen peroxide, like other ROS, leads to an oxidative stress (pessarakli, 2010).

Rosemary (Rosmarinus officinalis L.) is an evergreen, perennial, shrubby plant which has been widely cultivated since the ancient times as a medicinal herb and landscape plant (Tounekti et al., 2008; Mateu-Andres et al., 2013; Hamidi Moghaddam et al., 2019). However, it is moderately salt tolerant (Alarcón et al., 2006; Tounekti et al., 2008; Kiarostami et al., 2010; Tounekti et al., 2011b).

Most regions of Iran are classified as arid and semi-arid due to limited rainfall; high amount of evaporation as well as high temperature and salinity are the most severe restriction to plant production in these regions. On the other hand, the plant response is different to environmental stresses and their adaptation ability is dependent to type, intensity, duration of the stress and other environmental factors (Hamidi Moghaddam et al., 2019). Therefore, further research is needed to understand the interaction between UV-B radiation and salinity and their effects on the plant physiological and biochemical parameters. The purpose of this study was to evaluate the effect of different levels of ultraviolet $B$ radiation on growth, physiological and biochemical changes of rosemary plant and whether these treatments would improve its tolerance to salinity stress.

\section{MATERIALS AND METHODS}

In order to evaluate the effects of the UV-B radiation and salinity stress on some physiological and biochemical responses of the rosemary plant, an experiment was conducted in a split-plot arrangement in Randomized Complete Design (RCD) with four replications in a greenhouse. The experimental treatments involved UV-B irradiation at three levels $\left(0,4.32\right.$ and $\left.6.05 \mathrm{~kJ} \mathrm{~m}^{-2} \mathrm{~d}^{-1}\right)$ assigned to main plots, salinity stress in four levels (control, 50, 100 and $150 \mathrm{mM} \mathrm{NaCl}$ ) as a subplot. The UV-B radiation was provided by UV fluorescent lamps (TL $40 \mathrm{~W} / 12 \mathrm{RS}$, with a peak at 313 $\mathrm{nm}$; Phillips, Germany). The lamps were wrapped with $0.127 \mathrm{~mm}$ cellulose diacetate foil (CA), which filters radiation below $280 \mathrm{~nm}$ (UV-C radiation). In order to avoid photo-degradation of CA by the UV radiation, they were replaced weekly. The spectral irradiance from the lamps was determined with a UV spectro-radiometer (MSS2040, MSSElectronic-Gmbh, Germany). In order to prevent the UV radiation contamination among plots, they were separated by polyester. Salinity treatments started eight weeks after applying the UV-B treatments and sampling took place six weeks later.

At the end of the experiment, roots and shoots were immediately separated and washed. After they were dried naturally under suitable dry and dark conditions, their weight was determined. The relative water content was measured with the method proposed by Ritchie et al. (1990). The concentrations of $\mathrm{K}^{+}$and $\mathrm{Na}^{+}$in rosemary leaves and roots were analyzed by means of the method of Kalra (1998) using a Flame photometer (JENWAY PFP7, UK) and expressed as $\mathrm{mg} \mathrm{g}^{-1} \mathrm{DW}$. The quantities of photosynthetic pigments were determined with the method proposed by Lichtenthaler (1987) using a spectrophotometer (Cecil, CE 2502, UK). Measurement of total soluble sugar (TSS) were determined with the anthrone 
reagent method as described by Wardlaw and Willenbrink (1994) and expressed as mg of glucose equivalents per $\mathrm{g}^{-1} \mathrm{FW}$ through a standard calibration curve of glucose. The concentration of proline in rosemary leaves was measured by means of the method of Bates et al. (1973) and its amount was expressed as $\mu \mathrm{mol} \mathrm{g} \mathrm{g}^{-1} \mathrm{FW}$ through a standard calibration curve of proline. The Malondealdehyde (MDA) Concentration was determined based on the method described by Heat and Packer (1968). The measurement of hydrogen peroxide $\left(\mathrm{H}_{2} \mathrm{O}_{2}\right)$ was done through the method described by Alexieva et al. (2001) and expressed as $\mu \mathrm{M}^{-1} \mathrm{~g}^{-1} \mathrm{FW}$ through a standard calibration curve of hydrogen peroxide. The concentration of total phenolic compounds (TPC) were measured with the Folin-Cicoalteu colorimetric method as described by Singleton et al. (1999) and the amount of them was expressed as mg of gallic acid equivalents (GAE) per gram of fresh weight through a standard calibration curve of gallic acid. The antioxidant activity of the rosemary extracts was estimated on the basis of the scavenging activity of the stable 1, 1-diphenyl 2-picrylhyorazyl (DPPH) free radical according to the method explained by Hanato et al. (1988) and expressed as $\mathrm{IC}_{50}\left(\mu \mathrm{g} \mathrm{ml}^{-1}\right)$.

\section{RESULTS AND DISCUSSION}

\section{Shoot biomass}

The shoot biomass was significantly affected by both treatments $(\mathrm{P}<0.01)$. The UV-B radiation and salinity stress acted in an opposing manner, the plants grown under 4.32 and $6.05 \mathrm{~kJ} \mathrm{~m}^{-2} \mathrm{~d}^{-1}$ UV-B radiation had $17.88 \%$ and $10.69 \%$ greater biomass than the seedlings grown under zero (Fig. 1). In contrast, the salinity treatments decreased the shoot biomass. The interaction between the UV-B radiation and salinity stress was shown that $(\mathrm{P} \leq 0.01)$, in the plant grown under zero level UV-B radiation, the shoot biomass gradually decreased with an increasing level of salinity (Fig. 1). The lowest shoot biomass (33.68 g) was observed in the plants treated with $150 \mathrm{mM} \mathrm{NaCl}$ in comparison to control $(41.11 \mathrm{~g})$. On the other hand, the UV-B treatments significantly increased the shoot biomass at 50 and $100 \mathrm{mM} \mathrm{NaCl}$ than the seedlings grown under zero.

Several studies on the effects of UV-B radiation on plant biomass have been carried out but the results were contradictory; some reported that
UV-B radiation increased biomass in Ocimum basilicum L. (Sakalauskaite et al., 2013), Laurus nobilis L. (Bernal et al., 2015) and Prunella vulgaris L. (Zhang et al., 2017) whereas, in Catharanthus roseus L. (Guo et al., 2014), Glycine max L. and Zea mays L. (shen et al., 2015) plant biomass decreased by UV-B radiation. This difference could be related to plant species, developmental stage, duration and intensity of UV-B radiation (Kakani et al., 2003). In our experiment, an increase in the shoot biomass could be due to the positive effect of UV-B radiation on the number of leaves and axillary shoots of rosemary plants (Hamidi Moghaddam et al., 2019).

Similar results have also been reported regarding the effect of salinity stress (Kiarostami et al., 2010; Hejazi Mehrizi et al., 2012; El-Esawi et al., 2017; Nahrjoo and Sedaghathoor, 2018) on rosemary biomass. Water deficit under saline conditions, which is caused by low osmotic potentials, could lead to the decreases of cell turgor pressure. This is the major cause of inhibition of plant cell elongation under salinity (Manchanda and Garg, 2008). It was also reported that salt accumulation in the old leaves accelerates cell death and thus decreases the supply of carbohydrates and plant growth regulators to the meristematic regions, consequently inhibiting growth. In fact, plant growth is decreased by a reduction in the photosynthesis rate and by an excessive uptake of salts. (Azza Mazher et al., 2007 and AcostaMotos et al., 2017).

\section{Relative water contents}

Relative water contents (RWC) were significantly $(\mathrm{P} \leq 0.01)$ affected by the UV-B radiation

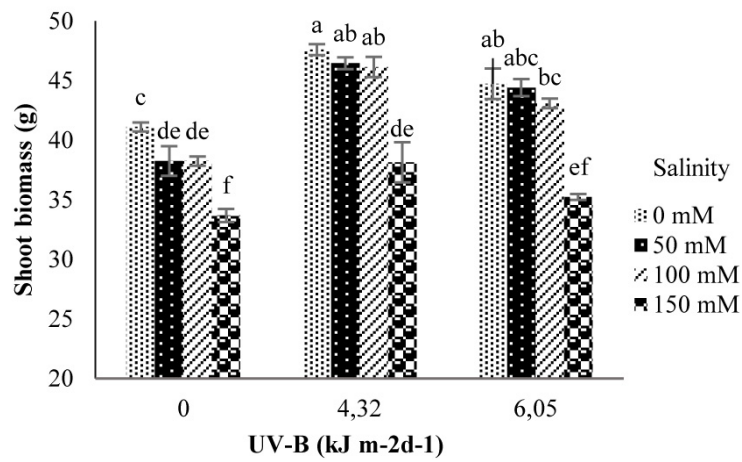

Fig. 1. Interaction between UV-B Radiation and salinity on shoot biomass. Values are mean \pm standard error $(n=4)$. Different letters indicate statistical differences between treatments using Tukey's HSD $(\mathrm{P} \leq 0.05)$ 
and salinity stress. The interaction between the UV-B radiation and salinity stress showed that $(\mathrm{P} \leq 0.05)$ in the plants grown under zero level of the UV-B radiation, the RWC were negatively impacted by the increase of salinity, as, the highest foliar RWC was observed in control and 50 $\mathrm{mM}$ salinity levels (Fig. 2). On the other hand, the plants grown in plot with $4.32 \mathrm{~kJ} \mathrm{~m}^{-2} \mathrm{~d}^{-1} \mathrm{UV}-\mathrm{B}$ radiation had relatively higher leaf RWC at 100 $\mathrm{mM}$ salinity compared to those grown under zero level of UV-B radiation (Fig. 2).

Leaf relative water content (RWC) is an index that directly reflects the water status of plant under stress condition and shows the ability of plants in maintaining water under stress conditions. Moreover, it is mainly dependent on the water status of the rhizosphere (Saied et al., 2005 and Saeed et al., 2014). It has been reported that the salinity stress decreased the water absorption capacity of root systems and water loss from leaves accelerated. Moreover, high salinity resulted in high osmotic pressure, which restricted the water

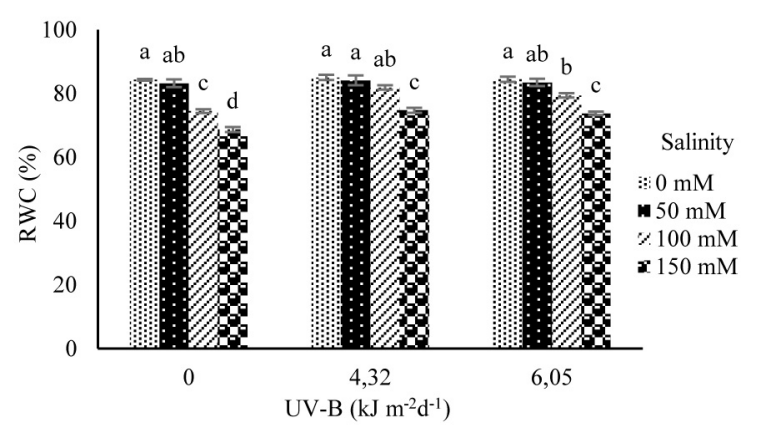

Fig. 2. Interaction between UV-B Radiation and salinity on relative water content (RWC). Values are mean \pm standard error $(n=4)$. Different letters indicate statistical differences between treatments using Tukey’s HSD $(\mathrm{P} \leq 0.05)$ uptake of plant cells, so the decreased moisture content may be due to defect metabolism in plant cells (Gupta and Huang, 2014 and Sadia et al., 2016). The present study confirmed the previous reports (Tounekti et al., 2011b; Hejazi Mehrizi et al., 2012 and Sadia et al., 2016) that salinity stress decreased RWC in rosemary plant. However, the mechanisms of the UV-B radiation and combination of these stress factors on RWC are still largely unknown, but Manetas et al. (1997) reported that restriction in stomatal opening and increase in cuticle thickness and epicuticular waxes of Pinus pinea L. leaves by UV-B radiation could have resulted in improving the leaf RWC. In addition, Alexieva et al. (2001) suggested that the control of RWC by UV-B treatment can be related to the induction of osmolytes or stress proteins faster than those induced by other stress.

\section{$\mathrm{K}^{+}$and $\mathrm{Na}^{+}$content}

The concentration of $\mathrm{K}^{+}$and $\mathrm{Na}^{+}$in rosemary leaves and roots were significantly affected by the UV-B radiation and salinity stress. With increasing UV-B radiation, an increase $(\mathrm{P} \leq 0.01)$ in the concentration of $\mathrm{K}^{+}$in leaves and a reduction $(\mathrm{P} \leq$ $0.05)$ in its concentration in roots was observed. In contrast, the concentration of $\mathrm{Na}^{+}$in leaves and roots, decreased $(P \leq 0.01)$ and increased $(P \leq 0.05)$ respectively, with increasing UV-B radiation (Table 1). On the other hand, an increase in the concentration of $\mathrm{NaCl}$ in the nutrient solution led to a progressive accumulation of $\mathrm{Na}^{+}$ions in both leaves and roots $(\mathrm{P} \leq 0.01)$. In contrast, $150 \mathrm{mM} \mathrm{NaCl}$ salinity stress decreased $(\mathrm{P} \leq 0.01)$ the concentration of $\mathrm{K}^{+}$in leaves $(26.43 \%)$ and roots $(53.66 \%)$ in comparison to control. This decrease was more pronounced in roots than leaves (Table 1).

Table 1. Effect of UV-B Radiation and salinity stress on concentrations of $\mathrm{K}$ and $\mathrm{Na}$ in leaves and roots of Rosemary plant

\begin{tabular}{|c|c|c|c|c|c|c|c|}
\hline \multirow{2}{*}{\multicolumn{2}{|c|}{ Treatments }} & \multicolumn{3}{|c|}{ Leaf } & \multicolumn{3}{|c|}{ Root } \\
\hline & & \multirow{2}{*}{$\begin{array}{c}\mathrm{K}^{+} \\
\left(\mathrm{mg} \mathrm{g}^{-1} \mathrm{DW}\right)\end{array}$} & \multirow{2}{*}{$\begin{array}{c}\begin{array}{c}\mathrm{Na}^{+} \\
\left(\mathrm{mg} \mathrm{g}^{-1} \mathrm{DW}\right)\end{array} \\
38.46 \pm 5.75^{\mathrm{a}}\end{array}$} & \multirow{2}{*}{$\begin{array}{c}\begin{array}{c}\mathrm{K}^{+}: \mathrm{Na}^{+} \\
\text {ratio in leaf }\end{array} \\
2.22 \pm 0.41^{\mathrm{b}}\end{array}$} & \multirow{2}{*}{$\begin{array}{c}\mathrm{K}^{+} \\
\left(\mathrm{mg} \mathrm{g}^{-1} \mathrm{DW}\right) \\
19.11 \pm 1.39^{\mathrm{a}}\end{array}$} & \multirow{2}{*}{$\begin{array}{c}\begin{array}{c}\mathrm{Na}^{+} \\
\left(\mathrm{mg} \mathrm{g}^{-1} \mathrm{DW}\right)\end{array} \\
19.33 \pm 1.98^{\mathrm{b}}\end{array}$} & \multirow{2}{*}{$\begin{array}{c}\begin{array}{c}\mathrm{K}^{+}: \mathrm{Na}^{+} \\
\text {ratio in root }\end{array} \\
1.26 \pm 0.19^{\mathrm{a}}\end{array}$} \\
\hline \multirow{3}{*}{$\begin{array}{c}\text { UV-B } \\
\left(\mathrm{kJ} \mathrm{m}^{-2} \mathrm{~d}^{-1}\right)\end{array}$} & Control & & & & & & \\
\hline & 4.32 & $56.45 \pm 1.47^{a}$ & $34.07 \pm 5.12^{b}$ & $2.67 \pm 0.50^{\mathrm{a}}$ & $16.86 \pm 1.17^{b}$ & $19.98 \pm 2.25^{\mathrm{ab}}$ & $1.13 \pm 0.18^{b}$ \\
\hline & 6.05 & $56.30 \pm 1.68^{a}$ & $34.53 \pm 5.19^{b}$ & $2.64 \pm 0.51^{a}$ & $16.87 \pm 1.16^{b}$ & $20.34 \pm 2.08^{a}$ & $1.06 \pm 0.16^{b}$ \\
\hline \multirow{4}{*}{$\begin{array}{l}\text { Salinity } \\
(\mathrm{mM})\end{array}$} & Control & $63.30 \pm 0.59^{a}$ & $11.87 \pm 0.35^{d}$ & $5.39 \pm 0.22^{a}$ & $23.11 \pm 0.48^{a}$ & $10.91 \pm 0.18^{d}$ & $2.12 \pm 0.05^{a}$ \\
\hline & 50 & $56.96 \pm 0.65^{b}$ & $21.20 \pm 0.35^{c}$ & $2.70 \pm 0.06^{b}$ & $20.78 \pm 0.60^{b}$ & $14.70 \pm 0.30^{c}$ & $1.42 \pm 0.04^{b}$ \\
\hline & 100 & $54.20 \pm 0.65^{c}$ & $45.03 \pm 1.05^{b}$ & $1.21 \pm 0.04^{c}$ & $15.44 \pm 0.45^{c}$ & $21.76 \pm 0.35^{b}$ & $0.71 \pm 0.03^{c}$ \\
\hline & 150 & $46.96 \pm 0.57^{d}$ & $64.65 \pm 1.42^{a}$ & $0.73 \pm 0.02^{d}$ & $11.10 \pm 0.31^{d}$ & $32.15 \pm 0.41^{a}$ & $0.35 \pm 0.01^{d}$ \\
\hline
\end{tabular}

Values are mean \pm standard error ( $n=16$ for UV-B and 12 for salinity). Different letters in each column, for each factor indicate statistical differences between treatments using HSD $(\mathrm{P} \leq 0.05)$. 
In relation to the $\mathrm{K}^{+}$: $\mathrm{Na}^{+}$ratio in leaves and roots, the UV-B radiation $(\mathrm{P} \leq 0.01)$ significantly increased this ratio in leaves and decreased it in roots (Table 1). However, this ratio decreased in both leaves and roots $(\mathrm{P} \leq 0.01)$ with increasing salinity levels (Table 1).

It has been reported that the plant responses to enhanced UV-B radiation are complex, and may be the results of changes in various nutrient metabolic processes (Yue et al., 1998). Moreover, it might be associated with a "concentration" effect (Correia et al., 2012). On the other hand, salinity can rapidly decrease the capacity of roots to absorb essential nutrients from the soil. High levels of $\mathrm{Na}^{+}$in the soil can influence the root membrane integrity (Tounekti et al., 2008) and lead to a decrease in the $\mathrm{K}^{+}$concentration in plant tissues (Tuna et al., 2007). Additionally, the competition between $\mathrm{Na}^{+}$and $\mathrm{K}^{+}$for entry into plant root cells, could lead to a decrease in $\mathrm{K}^{+}: \mathrm{Na}^{+}$ratios and negatively impact the plant growth and development (Tuna et al., 2007). It seems that the UV-B radiation can maintain the membrane integrity and controls selectivity of ion uptake and transport via increasing the antioxidative activity under salinity condition.

\section{Photosynthetic pigments}

Although the contents of chlorophyll $a$, and total chlorophyll had not been affected by the enhanced UV-B radiation; however, the content of chlorophyll $b(\mathrm{P} \leq 0.05)$ and carotenoids $(\mathrm{P} \leq 0.01)$ decreased at both levels of enhanced UV-B radiation compared with zero (Fig. 3). On the other hand, the concentration of all photosynthetic pigments decreased $(\mathrm{P} \leq 0.01)$ by increasing of salinity stress levels (Fig. 4). The highest concentrations of $a, b$, Total Chlorophyll and Carotenoids was observed in the plants grown under control and $50 \mathrm{mM}$ salinity stress.

Reduction in the chlorophyll contents under high ultraviolet radiation may be due to the inhibition of its biosynthesis or degradation of these pigments and their precursors (Agrawal and Rathore, 2007). It has been reported that the reduction in the amount of chlorophyll could result from the effect of UV-B on expression of the genes encoding for chlorophyll binding proteins (Mishra et al., 2008).

It is well-known that the salinity stress enhances the production of ROS (pessarakli, 2010). Accumulation of these free oxygen radicals in

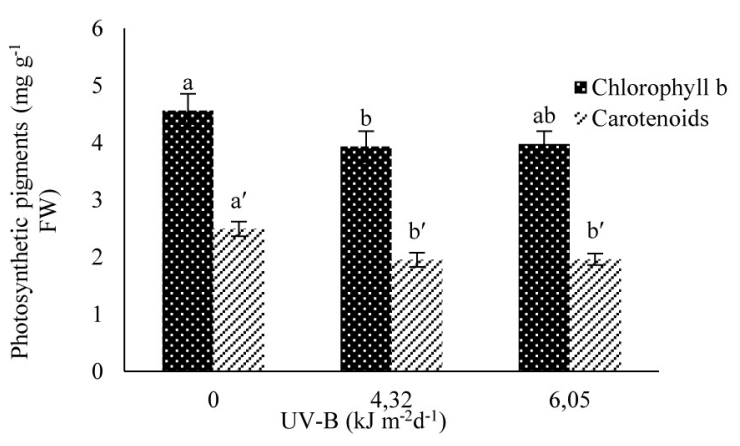

Fig. 3. Effect of UV-B radiation on the Chlorophyll $\mathrm{b}$ concentration. Values are mean \pm standard error $(n=16)$. Different letters indicate statistical differences between treatments using Tukey's HSD $(\mathrm{P} \leq 0.05)$

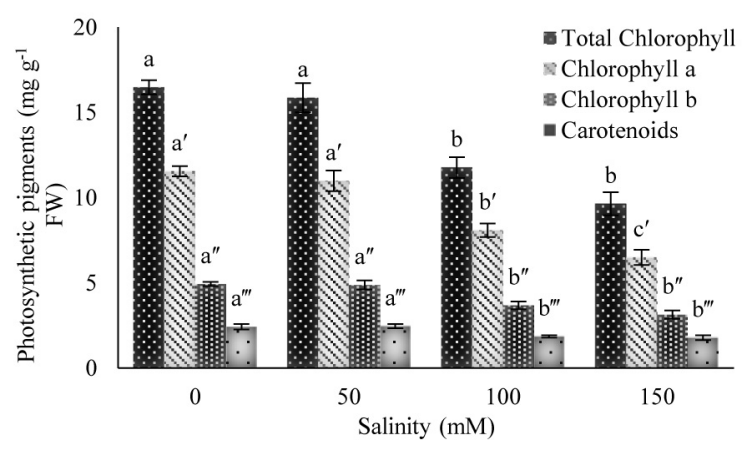

Fig. 4. Effects of salinity on photosynthetic pigments. Values are mean \pm standard error $(\mathrm{n}=12)$. Different letters indicate statistical differences between treatments using Tukey's HSD $(\mathrm{P} \leq 0.05)$

plant cells leads to peroxidation of unsaturated fatty acids of thylakoid membranes and consequently chlorophyll degradation enhanced (Miller et al., 2010). In addition, it could be related to the activity of chlorophyllase enzyme (Reddy and Vora, 1986). Kiarostami et al. (2010), Tounekti et al. (2011a), El-Esawi et al. (2017), Nahrjoo and Sedaghathoor (2018) reported similar findings related to photosynthetic pigments of the Rosemary plants under salinity stress.

\section{Total soluble sugars}

In relation to total soluble sugars (TSS), both treatments $\mathrm{UV}-\mathrm{B}$ radiation $(\mathrm{P} \leq 0.01)$ and $\mathrm{NaCl}$ salinity $(\mathrm{P} \leq 0.01)$ acted in an opposing manner (Fig. 5). The interaction between the UV-B radiation and salinity stress was shown that $(\mathrm{P} \leq 0.05)$ in a plant grown under zero level UV-B radiation, the concentration of TSS gradually increased along with the level of salinity (Fig. 5). The highest concentration of TSS (20.35 $\left.\mathrm{mg} \mathrm{g}^{-1} \mathrm{FW}\right)$ was observed in the plants treated with $100 \mathrm{mM}$ 
$\mathrm{NaCl}$ in comparison to control plants $(13.90 \mathrm{mg}$ $\mathrm{g}^{-1} \mathrm{FW}$ ). With further increases in salinity levels, the concentrations of TSS significantly decreased compared to $100 \mathrm{mM}$ salinity. On the other hand, the concentrations of TSS decreased in the leaves of rosemary plants which grew in the plots with 4.32 and $6.05 \mathrm{~kJ} \mathrm{~m}^{-2} \mathrm{~d}^{-1} \mathrm{UV}-\mathrm{B}$ radiation at control level of salinity (Fig. 5).

It is well-known that salinity, drought, low temperature and flooding increased the concentration of soluble sugars, whereas the UV-B radiation, heavy metals, nutrient shortage and ozone decreased it (Rosa et al., 2009). It has also been reported that the metabolism of soluble sugars could be a dynamic process which simultaneously involved the biosynthesis and degradation reactions (Rosa et al., 2009). Several studies have been carried out on the effects of UV-B radiation on the concentrations of TSS in plant tissue but the results were contradictory, some indicating increase in response to UV-B (Araújo et al., 2016; Aksakal et al., 2017) or decrease (Balouchi et al., 2009) and others indicating no alter (Javadmanesh et al., 2012). This may be due to the diversity of plant tissue or experimental conditions (Javadmanesh et al., 2012). However, a decrease in the concentrations of TSS under UV-B radiation may be due to supply of carbon skeleton to antioxidant compound synthesis such as UV-B absorbing and phenolic compounds (Interdonato et al., 2011). Moreover, it has also been related with the disruption of chloroplast structure, decrease of photosynthetic pigments and photosynthesis efficiency (Balouchi et al., 2009; Rosa et al., 2009).

On the other hand, Rosa et al., (2009) stated that soluble sugar fluctuations under salinity can be related with posttranslational activation and

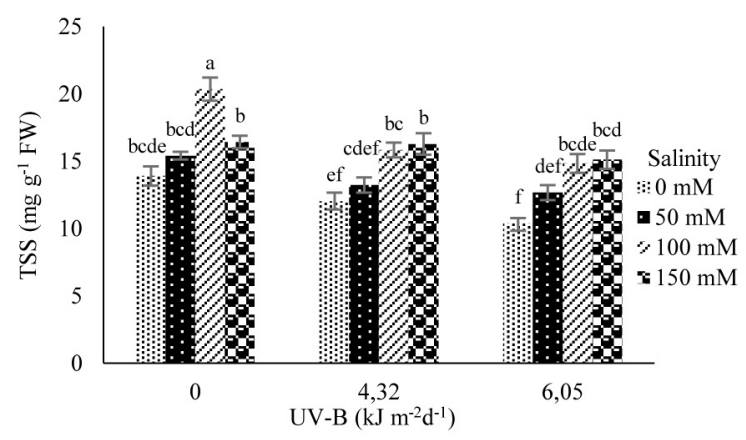

Fig. 5. Interaction between UV-B Radiation and salinity on total soluble sugars (TSS). Values are mean \pm standard error $(n=4)$. Different letters indicate statistical differences between treatments using Tukey’s HSD $(\mathrm{P} \leq 0.05)$ increased the expression of sucrose synthesis enzymes, and inhibition of enzymes of the Calvin cycle. Additionally, soluble sugars may act as a osmoregulator in plants which exposed to salinity and can increase the osmotic pressure of the cell (Javadmanesh et al., 2012). The present study confirmed the previous reports that salinity increased the total soluble sugars concentration in Ocimum basilicum (Heidari, 2012) and Lavandula multifida L. (Garc1'a-Caparro' et al., 2017).

\section{Proline content}

The proline content in the leaves of rosemary plant significantly increased under both enhanced UV-B radiation $(\mathrm{P} \leq 0.05)$ and $\mathrm{NaCl}$ salinity $(\mathrm{P} \leq$ 0.01 ) treatments (Fig. 6). The interaction between the UV-B radiation and salinity stress was shown that $(\mathrm{P} \leq 0.01)$, in the plant grown under zero level UV-B radiation, the concentration of proline gradually increased along with the level of salinity (Fig. 6).The plants grown under $150 \mathrm{mM}$ salinity level produced 9.6 times higher proline concentration than those grown under control. On the other hand, the enhanced UV-B levels (4.32 and $6.05 \mathrm{~kJ} \mathrm{~m}^{-2} \mathrm{~d}^{-1}$ ) significantly increased the proline concentration at control and $50 \mathrm{mM}$ salinity levels than zero level UV-B (Fig. 6).

Proline accumulation in a plant during UV-B exposure might be one of the modes to counteract the UV radiation promoted free radical generation and it might have the capacity to scavenge or to reduce the production of free radicals (Saradhi et al., 1995). The removal of excess $\mathrm{H}^{+}$occurring as a result of proline synthesis may have a positive effect on the reduction of the UV-B induced damage (Alexieva et al., 2001).

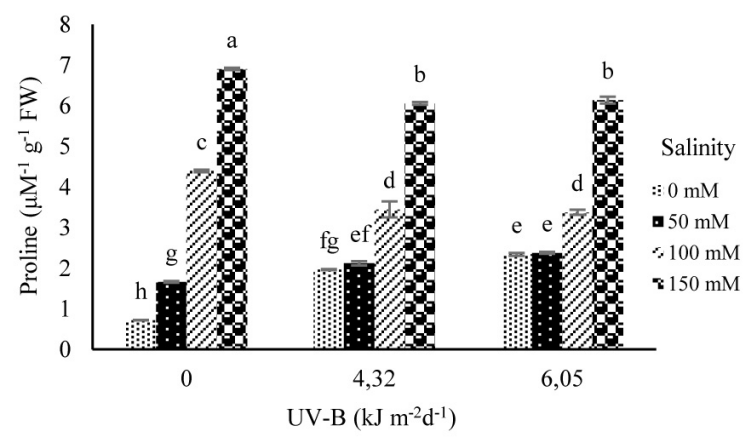

Fig. 6. Interaction between UV-B Radiation and salinity on proline content. Values are mean \pm standard error $(n=4)$. Different letters indicate statistical differences between treatments using Tukey's HSD $(\mathrm{P} \leq 0.05)$ 
On the other hand, proline acts as an osmoregulator and accumulation of it may help to maintain the relatively high water content necessary for growth and cellular function (pessarakli, 2010; Tounekti et al., 2011a). The present study confirmed the previous reports (Kiarostami et al., 2010; Hejazi Mehrizi et al., 2012; El-Esawi et al., 2017; Nahrjoo and Sedaghathoor, 2018) that the salinity stress increases proline accumulation in rosemary plant.

\section{Hydrogen Peroxide}

Both the UV-B radiation $(\mathrm{P} \leq 0.05)$ and salinity $(\mathrm{P} \leq 0.01)$ treatments induced a significant increase in the hydrogen peroxide $\left(\mathrm{H}_{2} \mathrm{O}_{2}\right)$ concentration (Fig. 7). The interaction between the UV-B radiation and salinity stress showed that $(\mathrm{P} \leq 0.01)$ in the seedlings grown under zero level UV-B radiation, the concentration of $\mathrm{H}_{2} \mathrm{O}_{2}$ gradually increased along with the level of salinity (Fig. 7). The highest concentration of $\mathrm{H}_{2} \mathrm{O}_{2}\left(12.7 \mu \mathrm{M}^{-1} / \mathrm{g}\right.$ FW) was observed in the plants treated with 150 $\mathrm{mM} \mathrm{NaCl}$ in comparison to control plants $(6.17$ $\left.\mu \mathrm{M}^{-1} / \mathrm{g} \mathrm{FW}\right)$. Both enhanced UV-B treatments significantly decreased the $\mathrm{H}_{2} \mathrm{O}_{2}$ concentration at $150 \mathrm{mM}$ salinity treatments than zero level UV-B.

Acceleration in the production or accumulation of ROS such as $\mathrm{H}_{2} \mathrm{O}_{2}$, is a general reaction to different abiotic and biotic stresses (Kovtun et al., 2000). There are many other reports that confirmed the results of this study that the UV-B radiation (Alexieva et al., 2001; Rai et al., 2011; Shen et al., 2015; Zhang et al., 2017) and salinity (Tanou et al., 2009; Varshney et al., 2013; ElEsawi et al., 2017; Tanaka et al., 2018) lead to excessive generation and accumulation of $\mathrm{H}_{2} \mathrm{O}_{2}$.

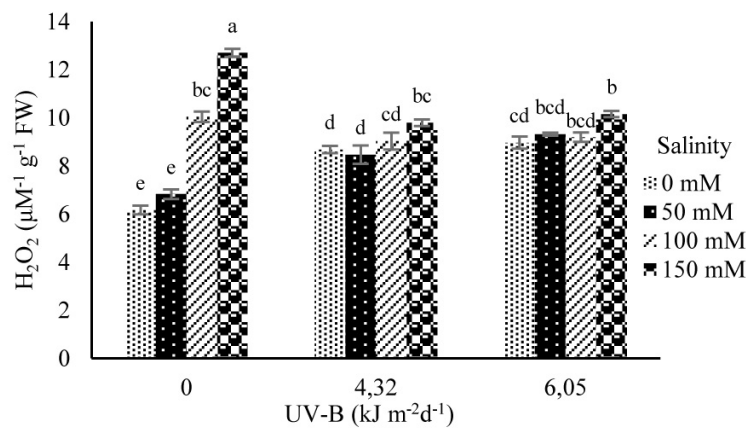

Fig. 7. Interaction between UV-B Radiation and salinity on concentration of hydrogen peroxide $(\mathrm{H} 2 \mathrm{O} 2)$. Values are mean \pm standard error $(\mathrm{n}=4)$. Different letters indicate statistical differences between treatments using Tukey's HSD $(\mathrm{P} \leq 0.05)$
Although the mechanisms for producing reactive oxygen species by ultraviolet $\mathrm{B}$ radiation and salinity stress are not well understood, it has been reported that the ultraviolet $\mathrm{B}$ radiation (Rao et al., 1996) and salinity stress (Tanou et al., 2009) increase the production of reactive oxygen species by increasing the activity of membrane-localized NADPH-oxidase.

\section{Malondealdehyde (MDA)}

Both the UV-B radiation $(\mathrm{P} \leq 0.05)$ and salinity stress treatments $(\mathrm{P} \leq 0.01)$ increased the concentration of MAD in leaves (Fig. 8). The interaction between UV-B radiation and salinity stress showed that $(\mathrm{P} \leq 0.01)$ in the seedlings grown under zero level UV-B radiation, the concentration of MDA gradually increased along with the level of salinity (Fig. 8), The highest degree of lipid peroxidation was observed in the rosemary plants treated with $150 \mathrm{mM} \mathrm{NaCl}(12.06 \mathrm{nmol} / \mathrm{g} \mathrm{FW})$ in comparison to control plants $(6.94 \mathrm{nmol} / \mathrm{g} \mathrm{FW})$. On the other hand, the enhanced UV-B radiation 4.32 and 6.05 $\mathrm{kJ} \mathrm{m}^{-2} \mathrm{~d}^{-1}$ significantly increased the MDA concentration at control level of salinity and decreased it at $150 \mathrm{mM}$ salinity compared to the plants growing under zero level UV-B (Fig. 8).

Lipid peroxidation is a normal metabolic process associated with the developmental processes of plants and increase in its levels by environmental stresses parallel with the increase in ROS production (pessarakli, 2010). In the present study, the MDA levels in rosemary leaves significantly increased under the enhanced UV-B radiation and high levels of salinity, indicating increased lipid peroxidation of cell membrane and could reflect the increase in the damage caused by these

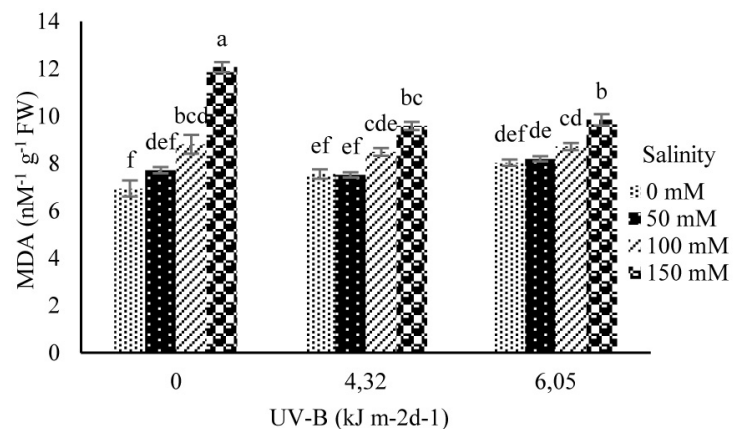

Fig. 8. Interaction between UV-B Radiation and salinity on concentration of malondealdehyde (MAD). Values are mean \pm standard error $(n=4)$. Different letters indicate statistical differences between treatments using Tukey's HSD $(\mathrm{P} \leq 0.05)$ 
treatments. Considering that there was a significant correlation between the MAD concentration and $\mathrm{H}_{2} \mathrm{O}_{2}(\mathrm{r}=-0.91)$, it can be concluded that the increased MAD concentration is probably due to the accumulation of $\mathrm{H}_{2} \mathrm{O}_{2}$ in the leaves. Increasing the lipid peroxidation by UV-B radiation in another plants such as Salvia officinalis L. (Radyukina et al., 2011), Artemisia annua L. (Rai et al., 2011), Prunella vulgaris L. (Zhang et al., 2017) and also by salinity stress in Rosmarinus officinalis L. (Tounekti et al., 2011a; Hejazi Mehrizi et al., 2012), Thymus vulgaris L. and Origanum vulgare L. (Tanaka et al., 2018) has been reported.

\section{Total phenolic compounds (TPC)}

The concentration of TPC in leaves of rosemary was significantly affected by both treatments involving UV-B radiation and salinity stress $(\mathrm{P} \leq$ $0.01)$. The interaction between the UV-B radiation and salinity stress showed that $(\mathrm{P} \leq 0.01)$ in the plants grown under zero level UV-B radiation (Fig.9), total phenolic contents gradually increased along with the rates of salinity up to 100 $\mathrm{mM}$ (40.85 mg GAE/g FW) compared to control (14.46 mg GAE/g FW). With further increases in salinity levels, phenolic contents significantly decreased compared to $100 \mathrm{mM}$ salinity. However, it was significantly higher compared to control and $50 \mathrm{mM}$ salinity (Fig. 9). On the other hand, the plants grown under both enhanced UV-B radiations had more TPC at control and $50 \mathrm{mM}$ salinity compared to the zero UV-B.

Phenolic compounds may play an important role as antioxidants by scavenging the free radicals produced under oxidative stress (Giorgi et al., 2009 and Bernal et al., 2013). It is widely

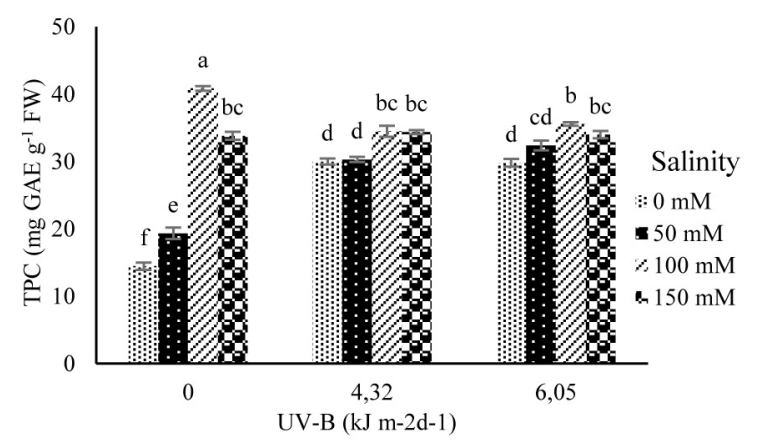

Fig. 9. Interaction between UV-B Radiation and salinity on total phenolic compounds (TPC). Values are mean \pm standard error $(n=4)$. Different letters indicate statistical differences between treatments using Tukey's HSD $(\mathrm{P} \leq 0.05)$ accepted that the metabolism of phenolic compounds is up-regulated by a wide range of environmental stresses, such as the UV-B radiation (Luis et al., 2007; Bernal et al., 2015; Shen et al., 2015; Zhang et al., 2017) and salinity (Kiarostami et al., 2010; Tounekti et al., 2011a; Hejazi Mehrizi et al., 2012; Sadia et al., 2016; El-Esawi et al., 2017; Valifard et al., 2015), which have the generation of ROS in common (Alam et al., 2015; Bernal et al., 2015). It has also been assumed that ROS act as a primary signal for the activation of phenylalanine ammonia lyase (PAL), the key enzyme of the phenylpropanoid metabolism, leading to an acceleration of the biosynthesis of phenolic compounds (Eichholz et al., 2011; Surjadinata et al., 2017).

\section{Antioxidant activity}

Both UV-B radiation salinity treatments increased the antioxidant activity $(\mathrm{P} \leq 0.01)$ which was expressed based on $\mathrm{IC}_{50}$ (Fig. 10). The interaction between UV-B radiation and salinity stress was shown that, in seedlings grown under zero level UV-B radiation, antioxidant activity gradually increased along with the rates of salinity. The lowest and the highest values of antioxidant activity were observed in the leaves of plants growing under non-saline conditions $(25.94 \mu \mathrm{g} / \mathrm{ml})$ and $150 \mathrm{mM}$ salinity $(17.35 \mu \mathrm{g} / \mathrm{ml})$, respectively (Fig. 10). On the other hand, both enhanced UV-B treatments (4.32 and $\left.6.05 \mathrm{~kJ} \mathrm{~m}^{-2} \mathrm{~d}^{-1}\right)$ significantly increased the values of antioxidant activity at control level of salinity compared to the plants growing under zero level UV-B (Fig. 10).

In this research, the radical-scavenging activity of rosemary extract was significantly increased

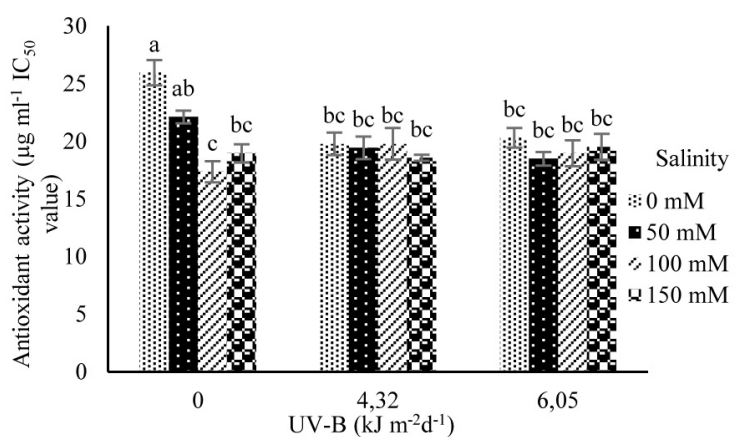

Fig. 10. Interaction between UV-B Radiation and salinity on antioxidant activity. Values are mean \pm standard error $(n=4)$. Different letters indicate statistical differences between treatments using Tukey's HSD $(\mathrm{P} \leq 0.05)$ 
by the UV-B radiation and salinity stress, indicating that the antioxidant capacity was stimulated by these treatments. Similar results have also been reported regarding the effect of UV-B radiation (Luis et al., 2007) and salinity stress (Kiarostami et al., 2010; Hejazi Mehrizi et al., 2011;) on the antioxidant activity of rosemary extract. As already mentioned, when exposed to environmental stresses the ROS accumulation in plant cells causes an oxidative damage to lipids, proteins, and nucleic acids. Plants have developed various enzymatic and non-enzymatic detoxification mechanisms in order to avoid oxidative damage (pessarakli, 2010). In this regard, phenolic compounds may play a very important role as the scavenging of ROS (Giorgi et al., 2009). Considering that there was a significant correlation $(\mathrm{r}=$ 0.94) between the amount of TPC and antioxidant activity, it can be deduced that a change in the antioxidant activity by UV-B radiation and salinity stress probably resulted due to the differences in the amount of TPC. This correlation is widely reported in other species such as yarrow (Giorgi et al., 2009), buckwheat (Tsurunaga et al., 2013), purslane (Alam et al., 2015).

\section{CONCLUSIONS}

Our results showed that the rosemary plant is relatively sensitive to salinity due to the increase in lipid peroxidation and cell membrane permeability to $\mathrm{Na}^{+}$. Pre-exposure of the rosemary plants to UV-B radiation increased the biomass production and improved the plant resistance to salinity stress. This could be related to UV-B induced improvement of the $\mathrm{K}^{+}$concentration in leaves, RWC, membrane stability and activation of similar protective mechanisms. Therefore, it can be supposed that pre-treatment with UV-B radiation alleviated the adverse effects of $\mathrm{NaCl}$ on rosemary growth and the existence of crosstolerance is presumed. However, further studies are required to testify to this concept.

\section{REFERENCES}

1. Acosta-Motos J.R. Ortuño M.F. Bernal-Vicente A. Diaz-Vivancos P. Sanchez-Blanco M.J. Hernandez J.A. 2017. Plant Responses to Salt Stress: Adaptive Mechanisms. Agronomy. 7 (1), 18.

2. Agrawal S.B. Rathore D. 2007. Changes in oxidative stress defense system in wheat (Triticum aestivum L.) and mung bean (Vigna radiate L.) cultivars grown with and without mineral nutrients and irradiated by supplemental Ultraviolet-B. Environmental and Experimental Botany. 59: 21-23.

3. Aksakal O. Tabay D. Esringu A. Aksakal F.L. Esim N. 2017. Effect of proline on biochemical and molecular mechanisms in lettuce (Lactuca sativa L.) exposed to UV-B radiation. Photochemichal and. Photobiological. Sciences, 16: 246-254.

4. Alam Md.A. Juraimi A.S. Rafii M.Y. Hamid A.A. Aslani F. Alam M.Z. 2015. Effects of salinity and salinity-induced augmented bioactive compounds in purslane (Portulaca oleracea L.) for possible economical use. Food Chemistry, 169: 439-447.

5. Alarcón J.J. Morales M.A. Ferrández T. SánchezBlanco M.J. 2006. Effects of water and salt stresses on growth, water relations and gas exchange in Rosmarinus officinalis. Journal of Horticultural Science and Biotechnology. 81: 845-853.

6. Alexieva V. Sergiev I. Mapelli S. Karanov E. 2001. The effect of drought and ultraviolet radiation on growth and stress markers in pea and wheat. Plant Cell and Environment, 24: 1337-1344

7. Araújo M. Santos C. Costa M. Moutinho-Pereira J. Correia C. Dias M.C. 2016. Plasticity of young Moringa oleifera L. plants to face water deficit and UVB radiation challenges. Journal of Photochemistry \& Photobiology, B: Biology, 162: 278-285.

8. Azza Mazher A.M. El-Quesni E.M.F. Farahat M.M. 2007. Responses of ornamental plants and woody trees to salinity. World Journal of Agricultural Sciences, 3: 386-395.

9. Balouchi H.R. Sanavy S.A.M.M. Emam Y. Dolatabadian A. 2009. UV radiation, elevated $\mathrm{CO}_{2}$ and water stress effect on growth and photosynthetic characteristics in durum wheat. Plant Soil Environmental, 55 (10): 443-453.

10. Bates I.S. Waldern R.P. Tear I.D. 1973. Rapid determination of free praline for water stress studies. Plant and Soil. 39: 205-207.

11. Bernal M. Llorens L. Badosa J. Verdaguer D. 2013. Interactive effects of UV radiation and water availability on seedlings of six woody Mediterranean species. Physiologia Plantarum, 147: 234-247.

12. Bernal M. Verdaguer D. Badosa J. Abadía A. Lluisa J. Penuelas J. Núñez-Olivera E. Llorens L. 2015. Effects of enhanced UV radiation and water availability on performance, biomass production and photoprotective mechanisms of Laurus nobilis seedlings. Environmental and Experimental Botany, 109: 264-245.

13. Correia C.M. Coutinho J.F. Bacelar E.A. Gonçalves B.M. Björn L. Pereira J.M. 2012. Ultraviolet-B radiation and nitrogen affect nutrient concentrations and the amount of nutrients acquired by aboveground organs of maize. The Scientific World Journal. 2012, 1-11. 
14. Eichholz I. Huyskens-Keil S. Keller A. Ulrich D. Kroh L W. Rohn S. 2011. UV-B-induced changes of volatile metabolites and phenolic compounds in blueberries (Vaccinium corymbosum L.). Food Chemistry, 126: 60-64.

15. El-Esawi M.A. Elansary H.O. El-Shanhorey N.A. Abdel-Hamid A M.E. Ali H.M. Elshikh M.S. 2017. Salicylic Acid-regulated antioxidant mechanisms and gene expression enhance rosemary performance under saline conditions. Frontiers in Physiology, 8:716.

16. Garc1'a-Caparros P. Llanderal A. Pestana M. Correia P.J. Lao M.T. 2017. Lavandula multifida response to salinity: Growth, nutrient uptake, and physiological changes. Journal of Plant Nutrient and Soil Science, 180: 96-104.

17. Giorgi A. Mingozzi M. Madeo M. Speranza G. Cocucci M. 2009. Effect of nitrogen starvation on the phenolic metabolism and antioxidant properties of yarrow (Achillea collina Becker ex Rchb.). Food Chemistry, 114: 204-211.

18. Guo X.R. Chang B.W. Zu Y.G. Tang Z.H. 2014. The impacts of increased nitrate supply on Catharanthus roseus growth and alkaloid accumulations under ultraviolet-B stress. Journal of Plant Interactions, 9 (1): 640-646.

19. Gupta B. Huang B. 2014. Mechanism of Salinity Tolerance in Plants: Physiological, Biochemical, and Molecular Characterization. International Journal of Genomics. ID 701596.1-18.

20. Hamidi-Moghaddam A. Arouiee H. Moshtaghi N. Azizi M. shoor M. Sefidkon F. 2019. Visual Quality and Morphological Responses of Rosemary Plants to UV-B Radiation and Salinity Stress. Journal of Ecological Engineering, 20 (2): 34-43.

21. Hanato T. Kagawa H. Yasuhara T. Okuda T. 1988. Two new flavonoids and other constituents in licorice root: their relative astringency and radical scavenging effects. Chemical and Pharmaceutical Bulletin, 36: 2090-2097.

22. Hasanuzzaman M. Nahar K. Fujita M. 2013. Plant Response to Salt Stress and Role of Exogenous Protectants to Mitigate Salt-Induced Damages. In: Ahmad P. Azooz M.M. Prasad M.N.V. (eds) Ecophysiology and Responses of Plants under Salt Stress. Springer, New York, Heidelberg, Dordrecht, London.

23. Heath R.L. Packer L. 1968. Photoperoxidation in isolated chloroplast. I. Kinetics and stoichiometry of fatty acid peroxidation. Archives in Biochemistry and biophysics. 125:189-198.

24. Heidari M. 2012. Effects of salinity stress on growth, chlorophyll content and osmotic components of two basil (Ocimum basilicum L.) genotypes. African Journal Biotechnology, 11: 379-384.

25. Hejazi Mehrizi M. Shariatmadari H. Khoshgoftarmanesh A.H. Dehghani F. 2012. Copper Effects on growth, lipid peroxidation, and total phenolic content of rosemary leaves under salinity stress. Journal of Agriculture Science and Technology. 14: 205-212.

26. Hejazi Mehrizi M. Shariatmadari H. Khoshgoftarmanesh A.H. Moattar F. 2011. Effects of salinity and zinc nutrition on growth and antioxidant properties of Rosmarinus officinalis L. in a calcareous soil. Iranian Journal of Medicinal and Aromatic Plants, 27 (1): 25-35.

27. Interdonato R. Rosa M. Nieva C.B. Gonzalez J A. Hilal M. Prado F.E. 2011. Effects of low UV-B doses on the accumulation of UV-B absorbing compounds and total phenolics and carbohydrate metabolism in the peel of harvested lemons Environ. Environmental and Experimental Botany, 70: 204-211.

28. Javadmanesh S. Rahmani F. Pourakbar L. 2012. UV-B Radiation, Soil Salinity, Drought Stress and Their Concurrent Effects on Some Physiological Parameters in Mize Plant. American-Eurasian Journal of Toxicological Sciences, 4 (4): 154-164.

29. Kakani V.G. Reddy K.R. Zhao D. Sailaja K. 2003. Field crop response to ultraviolet-B radiation: a review. Agricultural and Forest Meteorology, 120: 191-218.

30. Kalra P.Y. 1998. Handbook of reference methods for plant analysis. CRC press.

31. Karima H. Salama A. 2009. Amelioration of NaClinduced alterations on the plasma membrane of $\mathrm{Al}$ lium cepa L. by Ascorbic Acid. Australian Journal of Basic and Applied Sciences. 3: 990-994.

32. Kiarostami K. Mohseni R. Saboora A. 2010. Biochemical changes of Rosmarinus officinalis under salt stress. Journal of Stress Physiology \& Biochemistry. 6: 114-122.

33. Kovtun Y. Chiu W-L. Tena G. Sheen J. 2000. Functional analysis of oxidative stress-activated mitogen-activated protein kinase cascade in plants. Proceedings of the National Academy of Sciences, USA, 97: 2940-2945.

34. Lichtenthaler K.H. 1994. Chlorophyll and carotenoids pigments of photosynthetic biomembrances. Methods in Enzymology. 148: 350-382.

35. Luis J.C. Martin Perez R. Valdes Gonzalez F. 2007. UV-B radiation effects on foliar concentrations of rosmarinic and carnosic acids in rosemary plants. Food Chemistry. 101: 1211-1215.

36. Mahajan S. Tuteja N. 2005. Cold, salinity and drought stresses: an overview. Archives of Biochemistry and Biophysics. 444:139-158.

37. Manchanda G. Garg N. 2008. Salinity and its effects on the functional biology of legumes. Acta Physiologiae Plantarum, 30: 595-618.

38. Manetas Y. Petropoulou Y. Stamatakis K. Nikopoulos D. Levizou E. Psaras G. Karabourniotis G. 1997. Beneficial effects of enhanced UV-B radiation under field conditions: improvement of needle 
water relations and survival capacity of Pinus pinea. Plant Ecology, 128: 101-108.

39. Marwood C.A. Greenberg B.M. 1996. Effect of Supplementary UVB Radiation on Chlorophyll Synthesis and Accumulation of Photosystems during Chloroplast Development in Spirodela oligorrhiza. Photochemistry and Photobiology. 64 (4): 664-670.

40. Mateu-Andrés I. Aguilella A. Boisset F. Currás R. Guara M. Laguna E. Marzo A. Puche M.F. Pedrola J. 2013. Geographical patterns of genetic variation in rosemary (Rosmarinus officinalis) in the Mediterranean basin. Botanical Journal of the Linnean Society. 171: 700-712.

41. McKenzie R.L. Aucamp P.J. Bais A.F. Bjorn L.O. IIyas M. Madronichg S. 2011 Ozone depletion and climate change: impacts on UV radiation. Photochemical and Photobiological Sciences. 10: 182-198.

42. Miller G. Suzuki N. Ciftci-Yilmaz S. Mittler R. 2010. Reactive oxygen species homeostasis and signaling during drought and salinity stresses. Plant, Cell and Environment. 33: 453-467.

43. Mishra V. Srivastava G. Prasad S.M. Abraham G. 2008. Growth, photosynthetic pigments and photosynthetic activity during seedling stage of cowpea ( $\mathrm{Vi}$ gna unguiculata) in response to UV-B and dimethoate. Pesticide Biochemistry and Physiology. 92: 30-37.

44. Nahrjoo M. Sedaghathoor S. 2018. The Induction of Salinity Stress Resistance in Rosemary as Influenced by Salicylic Acid and Jasmonic Acid. Communications in Soil Science and Plant Analysis. 49 (14):1761-1773.

45. Neill S.J. Desikan R. Clarke A. Hurst R.D. Hancock J.T. 2002. Hydrogen peroxide and nitric oxide as signalling molecules in plants. Environmental and Experimental Botany. 53 (372): 1237-1247.

46. Pessarakli M. 2010. Handbook of Plant and Crop Stress. Third Edition. CRC Press.

47. Radyukina N.L. Shashukova A.V. Makarova S.S. Kuznetsov V.V. 2011. Exogenous Proline Modifies Differential Expression of Superoxide Dismutase Genes in UV-B -Irradiated Salvia officinalis Plants. Russian Journal of Plant Physiology. 58 (1): 51-59.

48. Rai R. Meena R.P. Smita S.S. Shukla A. Rai S.K. Pandey-Rai S. 2011. UV-B and UV-C pre-treatments induce physiological changes and artemisinin biosynthesis in Artemisia annua L. - An antimalarial plant. Journal of Photochemistry and Photobiology B: Biology. 105: 216-225.

49. Rao M.V. Paliyath G. Ormrod D.P. 1996. Ultraviolet-B- and ozone-induced biochemical changes in antioxidant enzymes of Arabidopsis thaliana. Plant Physiology. 110: 125-136.

50. Reboredo F. Lidon F.J.C. 2012. UV-B radiation effects on terrestrial plants - A perspective. Emirates Journal of Food and Agriculture. 24 (6): 502-209.
51. Reddy M.P. Vora A.B. 1986. Changes in pigment composition, hill reaction activity and saccharides metabolism in bajra (Pennisetum typhoides $\mathrm{S} \& \mathrm{H}$ ) leaves under $\mathrm{NaCl}$ salinity. Photosynthica. 20: 50-55.

52. Ritchie S.W. Nguyen H.T. Halody A.S. 1990. Leaf water content and gas exchange parameters of two wheat genotypes differing in drought resistance. Crop Sciences. 30: 105-111.

53. Rosa M. Prado C. Podazza G. Interdonato R. Gonzalez J.A. Hilal M. Prado F.E. 2009. Soluble sugars-Metabolism, sensing and abiotic stress. Plant Signaling \& Behavior. 4 (5): 388-393.

54. Sadia B. Irfan S. Bazai Z.A. 2016. Chemical composition of rosemary (Rosmarinus officinalis L.) leaves under salt stress. Pure and Applied Biology. 5(2): 355-360.

55. Saeed R. Mirza S. Ahmad R. 2014. Electrolyte leakage and relative water content as affected by organic mulch in okra plant (Abelmoschus esculentus (L.) moench) grown under salinity. Fuuast Journal of Biology. 4 (2): 221-227.

56. Saied A.S. Keutgen A.J. Noga G. 2005. The influence of $\mathrm{NaCl}$ Salinity on Growth, Yield and Fruit Quality of Strawberry cvs. 'Elsanta'and 'Korona'. Scientia Horticulturea. 103: 289-303.

57. Sakalauskaite J. Viskelis P. Dambrauskiene E. Sakalauskiene S. Samuoliene G. Brazaityte A. Duchovskis P. Urbonaviciene D. 2013. The Effects of Different UV-B Radiation Intensities on Morphological and Biochemical Characteristics in Ocimum basilicum L. Journal of the Science of Food and Agriculture. 93: 1266-1271.

58. Saradhi P.P. Alia Arora S. Prasad K.V.S.K. 1995 Proline accumulates in plants exposed to UV radiation and protects them against UV induced peroxidation. Biochemical and Biophysical Research Communications. 209: 1-5.

59. Schreiner M. Mewis I. Huyskens-Keil S. Jansen M A.K. Zrenner R. Winkler J.B. O'Brien N. Krumbein A. 2012. UV-B-Induced Secondary Plant Metabolites - Potential Benefits for Plant and Human Health. Critical Reviews in Plant Sciences. 31 (3): 229-240.

60. Shen X. Dong Z. Chen Y. 2015. Drought and UV-B radiation effect on photosynthesis and antioxidant parameters in soybean and maize. Acta Physiologiae Plantarum. 37: 25.

61. Singleton V.L. Orthofer R. Lamuela-Raventos R M. 1999. Analysis of total phenols and other oxidation substrates and antioxidants by means of Folin-Ciocalteu reagent. Methods in Enzymology. 299: 152-178.

62. Surjadinata B B. Jacobo-Velázquez D A. CisnerosZevallos L. 2017. UVA, UVB and UVC Light Enhances the Biosynthesis of Phenolic Antioxidants in Fresh-Cut Carrot through a Synergistic Effect with Wounding. Molecules. 22, 668; doi:10.3390/ molecules22040668. 
63. Takshak S. Agrawal S.B. 2014. Effect of ultraviolet-B radiation on biomass production, lipid peroxidation, reactive oxygen species, and antioxidants in Withania somnifera. Biologia Plantarum. 58 (2): 328-334.

64. Tanaka H. Yamada S. Masunaga T. Yamamoto S. Tsuji W. Murillo-Amador B. 2018. Comparison of nutrient uptake and antioxidative response among four Labiatae herb species under salt stress condition. Soil Science and Plant Nutrition. DOI: 10.1080/00380768.2018.1492334.

65. Tanou G. Molassiotis A. Diamantidis G. 2009. Induction of reactive oxygen species and necrotic deathlike destruction in strawberry leaves by salinity. Environmental and Experimental Botany. 65: 270-281.

66. Tounekti T. Vadel A.M. Bedoui A. Khemira H. 2008. $\mathrm{NaCl}$ stress affects growth and essential oil composition in rosemary (Rosmarinus officinalis L.). Journal of Horticultural Science \& Biotechnology. 83: 267-273.

67. Tounekti T. Vadel A.M. Ennajeh M. Khemira H. Munné-Bosch S. 2011a. Ionic interactions and salinity affect monoterpene and phenolic diterpene composition in rosemary (Rosmarinus officinalis). Journal of Plant Nutrition and Soil Science. 174: 504-514.

68. Tounekti T. Vadel A.M. Onate N. Khemira H. Munné-Bosch S. 2011b. Salt-induced oxidative stress in rosemary plants: Damage or protection?. Environmental and Experimental Botany. 71: 298-305.

69. Tsurunaga Y. Takahashi T. Katsube T. Kudo A.K. Kuramitsu O. Ishiwata M. Matsumoto S. 2013. Effects of UV-B irradiation on the levels of anthocyanin, rutin and radical scavenging activity of buckwheat sprouts. Food Chemistry. 141: 552-556.
70. Tuna A.L. Kaya C. Ashraf M. Altunlu H. Yokas I. Yagmur B. 2007. The effects of calcium sulphate on growth, membrane stability and nutrient uptake of tomato plants grown under salt stress. Environmental and Experimental Botany. 59: 173-178.

71. Valifard M. Mohsenzadeh S. Niazi A. Moghadam A. 2015. Phenylalanine ammonia lyase isolation and functional analysis of phenylpropanoid pathway under salinity stress in 'Salvia' species. Australian Journal of Crop Science. 9 (7): 656-665.

72. Varshney K.A. Shukla A. Krishna V. Singh N B. 2013. Hydrogen Peroxide as A Signal Upstream Improving Salinity Tolerance in Alfalfa Plants. Indian Journal of Scientific Reseearh. 4 (2): 151-153.

73. Wang Y. Li X. Li J. Bao Q. Zhang F. Tulaxi G. Wang Z. 2016. Salt-induced hydrogen peroxide is involved in modulation of antioxidant enzymes in cotton. The Crop Journal. 4: 490-498.

74. Wardlaw I.F. Willenbrink J. 1994. Carbohydrate storage and mobilization by the culm of wheat between heading and grain maturity: the relation to sucrose synthase and sucrosephosphate synthase. Australian Journal of Plant Physiology. 21: 255-271.

75. Yue M. Li Y. Wang X. 1998. Effects of enhanced ultraviolet-B radiation on plant nutrients and decomposition of spring wheat under field conditions. Environmental and Experimental Botany. 40: 187-196.

76. Zhang X.R. Chen Y.H. Guo Q.S. Wang W.M. Liu L. Fan J. Cao L.P. Li C. 2017. Short-term UV-B radiation effects on morphology, physiological traits and accumulation of bioactive compounds in Prunella vulgaris L., Journal of Plant Interactions. 12 (1): 348-354. 